\title{
Colonial Basis of Anomie in African Youth: Implications for Political Governance
}

\author{
Taiwo A. Olaiya \\ Obafemi Awolowo University, Ile-Ife, Nigeria
}

\begin{abstract}
"Where a country ends up in terms of both ... level and ... structure depends in large part on where it begins" (Bird \& Zolt, 2005, p. 24)
\end{abstract}

\begin{abstract}
The festering phenomenon of morally deregulated conditions among African youths such as curricular impropriety, cult activities, from examination malpractice, cultism, viciousness, computer-related crimes, and sexual decadences depicts what Emile Durkheim (1893) used anomie to describe. Durkheim posited anomie as the inevitable expectations when societies become more complex, or organic, leading to impersonal behaviours, the dearth of the social bond, and normlessness. Emile Durkheim was a French Sociologist who had mobilised the coinage 'anomie' to explain the phenomenon of deregulated societies where interaction rules and expectations were breaking down. The demographic bulge in favour of youth in Africa has raised the stakes for the exacerbation of the lingering governance crisis should the youth continue to flounder in the disintegration of shared norms that hold the morality of societies firm from moral decadence. Most research studies have bordered on documenting that a good number of African youth have become enmeshed in depravities, such as lawlessness, violence, sharp practices, and scams. The focus of this paper provides an improved perspective by examining the social-economic and political foundations of irrational behaviour among African youth and the implications they portend. The paper argued that the youth in the modern States (former colonies) of Africa are unfortunate victims of a loose governance history: a manifestation of colonial masters' 'scramble for Africa' without a whiff of consideration for the fate of the youth and post-independent leaders, who simply continued in the same fashion. The modern-day political praxis in Africa of low participation of youth and lack of youth liberty and self-development is a carryover of not only the over-utilisation of elders as colonial proxies despite much aspiring youth but also the suppression of agitation by the youth against the commissioned elders. This conditioned many of the attitudes, which dominated policy-making and political victimisation of the youth in contemporary Africa. Thus, it is that colonial past that provided (or failed to provide) the definition of morality spectrum capable of insulating the youths against the festering anomic spree.
\end{abstract}

Keywords: Youth Anomie, Social Norms, Colonialism in Africa, Moral Decadence; Political Governance

DOI: $10.7176 / \mathrm{DCS} / 10-7-05$

Publication date:July $31^{\text {st }} 2020$

\section{Introduction}

Genuine concerns about youth engagement in maleficent activities are rife across global divides. The anxiety is not in the least directed at Africa since contemporary development studies have established the truism that for more than half a century now Africa is demographically characterised, above all else, by its youthfulness. Few would dispute that Africa requires a constant watch for global security with the continent alone accounting for about $20 \%$ of global youth population amidst "extraordinarily high rate of youth unemployment", infrastructural decay, political disenfranchisement and economic disempowerment, sex- and gender-based violence, rising drug abuse, poverty and abysmally low living conditions, youth restiveness, among others (UN, 2018, p. 26). Despite the high toll occasioned by the savagery of youth soldiers in various civil wars across the continent (both as cotravellers and victims) and the massive impact of HIV/AIDS, Ebola Virus, COVID-19, and other pandemics: the number has continued to increase. For instance, the average age of the population in East Africa is 17.5 years, and over two-thirds of the population falls between 24 years of age or under (Burgess \& Burton, 2010). Scholars have, however, argued variously that Africa's demographic diversity in favour of the youth promises a comparative advantage, which, if effectively harnessed, could provide the platform for advancing the development agenda (Adejumobi, 2011; Olaiya, 2014). Considering the demographic advantage, Lavender (2011) had argued that mainstreaming youth throughout Africa is an essential step in addressing the scourge of poverty and "in fact the source of hope for future transformation and an essential part of any holistic strategy to deal with poverty and its many symptoms". In this regards, the over two-third fraction constituting the youth gives the continent an edge in development quest since empowering the youth is always pivotal to achieving sustainable development and democratisation, as well as peaceful political governance. Despite, the neglect of the African youth at this moulding stage appeared to be the general rule, much as the marginalisation across the board- in politics, economy and society. While travelling across the Western part of the continent by early 1990s, Kaplan (1996) spotted a burgeoning Africa's youth crisis was in the offing. According to Kaplan, there were often ubiquitous yet lacklustre 
clusters of youths who were "out of school, unemployed, loose molecules in an unstable social fluid that threatened to ignite." Passing through the slums of Cote d'Ivoire, Kaplan found "Geology, like the birthrate" that "appeared to be unduly accelerating. Here, young unemployed men passed the time drinking beer, palm wine, and medicinally strengthened gin while gambling on pinball games... These are the same youths who rob houses at night in more prosperous Ivorian neighbourhoods.... The decaying, vegetal odour...was intense. Nature appeared far too prolific in this heat, and much of what she created spoiled quickly" (pp. 16-19).

The focus has been missing mainly of the dynamic attention deserved of studies on African youth, until perhaps recently. It may be true that "Africa is not unusual in this regard" because the recognition of 'youth' as a distinct group may be relatively recent too in other climes and appearing "in the course of the twentieth century" (Burgess \& Burton, 2010, p. 19). However, the case of Africa appears dimmer. Unlike advanced societies of the West, where the concept of "youth" as a discerning social group is getting developed, scholarship on Africa appears to have chosen to simply note the youthfulness of the population, recognising them only as a transitional category. Scanty attention, if any, is neither paid to labelling the youth as a 'discrete social—or analytical—group' nor treating the question of youth as a separate tool of concept (Burgess \& Burton, 2010, p. 19). Burgess and Burton (2010, p. 4) argued that even Kaplan's (1996) noteworthy claim that horde of idle, able-bodied youth "in West Africa constituted a serious potential threat to the security and stability of Western societies" went by unnoticed until after September 11,2001. As the technology advances to expand western influences into making the world a global village, the September 11 bombing of the WTC made it more evident that the West is neither immune from the challenges posed by endemic terrorist activities in the southern hemisphere, which is fanned by "poverty and injustice" among the youth. Burgess and Burton (2010) painted a graphical apocalypse that, due to failure of governance to provide education and job opportunities, the contemporary youth have become a keg of gunpowder waiting to explode and burn African societies.

While observations may differ about the exact nexus arising from population dynamics, underdevelopment, dwindling societal connections, and challenges of corrupt and violent politics, the fate of the youth as both victims and agents of the ensuing crises is well documented (Rodney, 1981; Olaiya, 2014). As Olaiya (2014) pointed out, the current low level of scholarly interest in youth-related issues is undoubtedly surprising considering the numerical strength of the young in Africa. Moreover, going by the potential and actual threats possessed and sometimes dissipated by the youth, much of the efforts on democracy, on democratisation and democracy consolidation, are better directed to this single most powerful category of citizens. Few would disagree with Burgess and Burton (2011) that it beats all imagination that, despite the youth constituting "a demographic majority from at least the middle of the last century, one may ask why youth has not attracted more attention". One may also wish to raise a critical question as to why youth issues have not occupied the front burners in African socioeconomic and political discourse? While scholarship and authorities prevaricate, the African continent has witnessed the manifestation of a neglected generation, both by threatening and in some cases liquidating existing social order and thus appearing to act from the background of a muffled voice. It also appears indisputable that "youth have played an obvious role in States collapse from Somalia to Sierra Leone" (Olaiya, 2014, p. 3) and "in the process of being "exploited by thugs and warlords" who enlist them to carry out violence and carriers of illegal arms and ammunitions for militia motives (Burgess \& Burton, 2011, p. 3).

Of late, however, it appears this situation has attracted commendable scholarly interest that has culminated in the development of a critical mass of literature on African youth-several continental conferences on youth held in recent times. For instance, the Government of Ghana, the African Union Commission (AUC), the United Nations Development Programme (UNDP) Regional Bureau for Africa (RBA) and the United Nations Economic Commission for Africa (ECA) jointly organised the Pre-Eighth African Governance Forum (AGF-VIII) multistakeholder Policy Dialogue on "Youth Empowerment, Elections and the Management of Diversity in Africa, which took place at the Fiesta Royale Hotel in Accra, Ghana on 28 - 29 November 2011. There was also the ECOWAS Workshop on Political Parties and Internal Party Democracy in Member States Abidjan, Cote d'Ivoire $21^{\text {st }}-23^{\text {rd }}$, July 2010, where issues relating to "Youth, Ethnic Movements and Party Politics in ECOWAS Member States" were vigorously debated. Burgess and Burton (2010) catalogued many other conferences and scholarly interests, focusing on African youth. He pointed out that it is a common practice nowadays to refer to "youth crisis," as an omnibus concept encapsulating many social ills in the society, which impinge more on the youth, "the general contours of which include accelerating urbanisation, chronic underemployment, delinquency, violence, and the spread of HIV/AIDS." In the introduction to an edited book entitled "Generations past: Youth in East African history", Burgess and Burton (2010) observed that the crisis appeared more rampant in the last years of the twentieth century, "when many states in Africa were no longer able to maintain patrimonial ties and networks sustained over previous decades, and underwent a process of contraction and at least partial collapse."

According to Burgess and Burton (2010), the 1980s and 1990s witnessed a horrendous situation in which multitudes of youthful persons lost faith in the constituted authorities for the institutional failure across all sectors that cater for their needs, namely security, job opportunities, and education. As such, the terrains that the youth currently ply, which has always been so since the colonial period in the form of "colonial racism, pre-existing 
urban hierarchies, and economic hardship" (Callaci, 2011, p. 375), are rough, competitive, and vexatious (Banks, 2016). Burgess and Burton (2010) quoted from Gavin's (2007, pp. 71-72) article titled "Africa's restless youth" in which the latter observed that "[m]any of Africa's youth are [now] caught in a Peter Pan scenario gone terribly wrong. Try as they might, they cannot seem to become adults" (p. 3). The writers took a special note from Abbink's (2005) work titled "Being young in Africa: The politics of despair and renewal". In that epic book, the writer stated that in addition to being even "victims of a "faulty modernisation'," being an African youth "has come to mean being disadvantaged, vulnerable, and marginal[ised]" (p. 3).

Hence, apart from the increased involvements of the youths in political violence and manipulations, it is now commonplace that youths are the more "available as unconscientious 'foot soldiers' of ethnic militias and terrorist groups" (Olaiya, 2014, p. 1) whose unholy mission is to foment pandemonium and political upheavals, (as though there is a consensus among the youths to 'pull down' the democracies they helped to enthrone). Just as the youth constituted a large reservoir that helped mobilised struggles and freedom missions against despotic leaders and arbitrariness, most notably in installing democratic rules and just society, in the late 1980s and 1990s, decades of political exclusion and neglect to decisively address the burgeoning challenges of job creation and provision of basic amenities, have resulted in a flurry of youth insurrections culminating in increased social, cyber, and violent/organised criminality and gangsterism, among others. The situation is no less illustrated in a classical work, edited by Abbink and van Kessel, titled "Vanguards or vandals youth: Politics and conflict in Africa". The authors vividly capture the volatility of the numerical strength of the youth, especially when the multitudes are not gainfully engaged. According to Burton (2010, p. 3), "the phenomenon of the child soldier, of a boy or girl at the same time vulnerable and ultra-empowered, speaks tragically of the limits to which young people in Africa could be pushed at the end of the twentieth century by poverty and hopelessness". Scholars with emotions for public image of Africa may probably disagree with this, but the instances being painted by the western press in the gory representations of African phenomenon aptly captured the tragic real-time situations. If anything, the graphics and literary representations remind the world of the sheer "capacity of youth - in limited and specific locations - to both resist and reproduce systems of violence and exploitation, to both desire and destroy the social order that provides a minimum of security and opportunity" (Burton, 2010, p. 3).

The primary submission of this work is that the crisis of the youth in postcolonial states of Africa is a crisis of the process of queer colonisation, identity configuration, and hurried decolonisation, exacerbated by the protonationalist, who fought for and inherited power without interrogating the States bequeathed to them. If the African leader achieved anything at all, such seemed momentary. At the brink of the independence declaration for Nigeria, Crowder (1987) wrote of time's glowing expectation of the sanctity of democratic values from the new state. As Siollun (2009) later puts it, the hoisting of the Nigerian Green and White flag, per its simplicity and graphical messages, in the first hour of October 1960 raised the sensibilities of a budding prosperous nation-state of a continent in search of leadership, identity and hope. Few would, therefore, dispute that Nigeria laid before the naked eyes "the prospect of a vibrant nation- especially one with the largest concentration of black people in the world and a sound agrarian economy with bountiful oil reserve waiting to be tapped, was more real than apparent" (Olaiya, 2016, p. 1). As Lavender (2011) has pointed out, "much of the positive momentum seen in the immediate post-colonial era was lost however, as the dreams of development began to crumble". The fate of the youth could not have been more battered than in "the period of economic crisis in the 1970s and 1980s, and the regime of structural adjustment and economic austerity programs presided over by the International Monetary Fund [that] saw dramatic cuts in government spending on public services like education, health and employment creation schemes". Thus, with the attendant inability to proffer workable solution for ameliorating the burden of unemployment and lack of strategic planning for educating the youth in the face of the dwindling economy, crime and political violence involving the youth exacerbated.

Studies have established the preeminent connection between postcolonial African politics and colonial rule (Callaci, 2011; Olaiya, 2014; Olaiya, 2016; Olaiya, 2019; Olaiya; 2020; Ekeh, 1975; Maclure and Denov, 2006; Boon \& Eyong, 2011). In a way, African political misadventure could be located as originated, or perhaps still originating, in how the states emerged as a colonial product and state-making and the proto-nationalistic struggles that preceded her freedom. Brautigham and Knack (2004, p. 255-256) argued "There are many reasons why governance is poor in much of sub-Saharan Africa. Colonialism did little to develop strong, indigenously rooted institutions that could tackle the development demands of modern states... and make it more difficult for good governance to develop". The authors further argued the states lacked the "capacity and institutions of governance" to address the needs of the youth, adding that "the newly independent nations of Africa were not well prepared... and many faced ethnic tensions that had been exacerbated by colonial rule" (p. 259). They lamented that the "local skill bases" of the states were not strong to drive the enormous youthful population into the mainstream of the economies (p. 259). As Olaiya (2016) argued, the nationalists were hardly interested in the ambitions for independent states but by a desire to rule and enjoy the trappings of the offices as the colonial officials did. Consequently, the countries that materialised lacked the necessary citizenship mobilisation, goal and strength, to strategise and deliver development agendas successfully. Not many could, therefore, dispute that the literary 
evocation of "African youth crisis" is a consequence of the years of neglect of the youth, resulting in - or led toa weakened societal engagement of Africa youth to the primordial ties that should nurture the youth and ushered them into adulthood. This article, therefore, intends to disprove the recurrent inducement in most literature on African studies that tend to present the pervasive youth anomie as though it were the creation of the postcolonial states. The mission is to push the idea that the crisis has been part and parcel of the slave trade era: only that the crisis exacerbated during the colonial era and became unmanageable by the postcolonial leaders.

Progressively, a new set of adaptation evolved. One is to take advantage of the situation around, whether it conforms to the norms or not. Having been economically and politically undermined, the youth have resorted to cyberspace empowerment and thereby constituting a network of invisible, if not invincible, criminals. Social networking services, the scientific advancement in cyberspace communication, constitute a radical change in information dissemination so much quicker than hitherto anticipated. Entities and individuals who could access the internet now utilise social media platforms such as Facebook, twitter, yahoo messenger, myspace, google+, Badoo and blackberry messenger, among others (Chengping, 2019). As the most active people and the most pressured to innovate, and with the demographic strength on their side, it was not difficult for African youth not only to be mainly influenced by the global ICT revolution but also to make their impact felt. In their inevitable drive for self-actualisation and with decades of cutthroat competition unleashed by joblessness, political and economic hardship, the global communication system especially in the social networks thus quickly provided an excellent opportunity for them to transform themselves into productive citizens.

Against the backdrop of being utilised as veritable agent for subtle political changes and the large-scale attendant unemployment and lack of economic empowerment, there is a growing restiveness of the youth that promises to shake the gains of democracy to its very foundation. Apart from the increased involvements of the youths in political violence and manipulations and as "foot soldiers" of ethnic militias and terrorist groups" (Olaiya, 2014, p. 2), it is now commonplace that youths are the more available as agents of online scams, cyberstalking and harassment, and program hacking. Just as the youth constituted a large reservoir for struggles against dictatorship, and helped to entrench multiparty democratic rule in the late 1980s and 1990s, decades of political exclusion and neglect to decisively address the growing unemployment among the youth and decaying social services have resulted in a flurry of youth counter-innovations to constitute themselves as organised movements utilising the unique opportunity offered by information super-highway revolution to create 'jobs' for themselves, culminating in dangers lurking in cyberspace, especially through social networking websites. Thus, even though the deviance of African youth has been part and parcel of history two critical social structures - cyberspace and youth - have played out to redefine the threat they pose to the political governance and socio-economic health of African states.

This article dabbled into the murky waters of colonialism as one of the overlooked explanations for the contemporary state of anomie in African youth. More than anywhere else, and with references drawn from local experiences of authors, the article linked the pattern of colonial practices and its postcolonial offshoots, to youth anomie. Building from the vast pool of scholarly works already existing on the subject, the article begins by outlining the significant contributions to anomie as a sociological explanation for group depravation. The article proceeded to review the extant literature on the present state of youth depravity and how they trudge in unemployment, squalor, poverty and lack of basic amenities, during and after school lives as opposed to how the adults of today fared in terms of suitable employment and infrastructures in times past. Many of them presently living in war and disease zones and functionally cut off from basic livelihood. The article briefly discusses the evolution of the present situation as a bye product of two scenarios: one which is occasioned by the lacklustre official attitude of the European colonisers who, while pursuing the so-called 'dual mandate' (Lugard, 1962), i.e. to develop Africa and fetch raw material for European companies, failed to factor the future of youth into the equation. As the article posited, the foray into Africa, as Lord Lugard bluntly described in his book "The Dual Mandate of the British in Tropical Africa", hardly involved planning that could provide a template for the engagement of the youth as stakeholders. It is "due primarily to the economic necessity of increasing the supplies of raw materials and food to meet the needs of Europe" and for "common greed...for which men and nations earn their bread and improve their standard of life" (Lugard, 1962, p. 613). As late as 1962, when he wrote the book, the lamentation of Lord Lugard, which vividly pictures the lots of the colonial youth, is instructive:

"I am... compelled to admit that, so far as my own experience goes, it is extremely difficult ...to

find educated African youths who... may rise to positions of high administrative responsibility" (p. 88).

The article discerned a peculiar pattern of colonisation in Africa, which is far removed from those of the Americas, Europe and Asia. On the other hand, the article grounded the equally negligent character of postcolonial leaders, who simply followed their erstwhile paymaster and continued in the tradition of the colonial practices and administration. Making Nigeria a conceptual representation of Africa is key to this study. As scholars have rightly observed, Nigeria may seem to represent the alter ego of Africa in many respects. Bandura and Hammond (2018) submitted that Nigeria is "Africa's economic powerhouse and ... on its way to becoming the 20th largest economy 
in the world by 2030 and the third most populous country by 2050". The authors posited further that, even though Nigeria's population is youthful and rapidly increasing in that direction, with the mass presence of pressurising "youth who are not afraid to take risks and voice concerns... the vast youth bulge will need to be employed in the future; otherwise, Nigeria risks further instability" (P. 1, 33). Just as Adebanwi (2010) similarly pointed out, Rotberg (2007) correctly wrote in "As Nigeria goes, so goes Africa" that Nigeria remains zero-typical of Africa in critical indices such as politics, pluralism, economic development, terrorism, underdevelopment and corruption.

\section{Theoretical foundation of 'anomie' in African youth}

In sociological parlance, anomie is the analysis of conditions of deregulation that occurs to elements of a society in which there is a breakdown in the cultural and social structure. How such perversions produce intense pressure for deviation in individuals or group of individuals has continued to draw quality attention of sociological debate. The concept is used to explain the current 'normlessness' and social disruption (political-economic depression, for instance) in African societies regarding high rates of crime, joblessness and poverty among the youth. The Merriam-Webster dictionary, an Encyclopaedia Britannica (online), define anomie as a "social instability resulting from the breakdown of standards and values" or a turning point in a society in which "personal unrest, alienation, and anxiety that comes from a lack of purpose or ideals" has become the order of the day. The conceptual introduction of the term 'anomie' dates back to 1893 and is often credited to the French sociologist, Emile Durkheim, consequent to the publication of the classic book, "The division of labour in society", in 1893. With particular reference to individuals in societies, Durkheim argued about a deregulated social system where the normative values and mutual expectations have disintegrated leading to perversions and lack of adherence to standard rules. Put simply, therefore, anomie refers to a societal stage in which norms or expected values have dissolved into a state of confusion or lack of clarity or at a loss. Durkheim argued that normlessness is closely connected with unruly behaviour, most especially deviant conducts.

The submissions of modern scholars arguably contrast the opinion expressed by Durkheim that a state of anomie strikes thunder-like and resulting in a systemic breakdown, either during a period of boom or that of a recession. Anomie, according to Merton (1957), does not occur in society by sudden flight, but a constitutive result of a steady collapse in norms on the part of the general populace or a striking change in the social status of some aspects in the society. He submitted that a chain reaction by elements begins to occur in a society leading to an infinitesimal and sustained decline in standard rules passed from generation to generation. The position of Merton (1938) is of particular relevance to this work. Here, we advance that the normlessness in African youths is better to the long period of neglect running through a trans-Atlantic slave and colonial legacies, proto-nationalisms, indigenous civilian and military rules characterised by profligacy, ethnic intolerance and disrespect for law and order over the time. In this regards, the anomie we refer to is the absence of morally accepted norms in social interaction within the youth combined with a condition in which activities of youth no longer confine themselves with the general regulations. Since norms passed from generation to generation guide transition from childhood to adulthood, it, therefore, becomes difficult to expect that individuals within societies can navigate in the absence of clearly defined rules of engagement.

Merton (1957) explored biological explanations of deviant behaviour and concluded that the nature and enormity of deviance exhibited from one society to the other is hardly explicable by consanguinity. Using functionalist perspective, Merton explained that inevitable deviance in a group is, for the most part, peculiar to them and can differ from corresponding groups of societies to societies and even similar subgroups within a single society. He argued that adopted cultural values in which breakdown in the norms within a culture creates deviance and lack of respect for rules by a particular group existing in a time-space plays a vital role, rather than traits and inherited values from past or adjoining generations. According to Merton (1979), anomie is the result where "there is an apparent lack of fit between the culture's norms, about what constitutes success in life (goals) and the culture's norms about the appropriate ways to achieve those goals (means)". The instructive effusion fits into the crux of this paper: a cardinal position here is that normlessness is the root of the desperate deviant behaviour in today's African youth.

Besides, it is becoming increasingly normative that success outweighs societal values. As Merton (1979) argued, when a society becomes successful and concurrently overpriced than being virtuous, a culturally approved means of achieving the success would be a trade-off. This is considered adaptable to the current situation for African youth, who grapple with unemployment, squalor, poverty and lack of basic amenities, during and after school lives as opposed to how the adults of today fared in terms of suitable employment and infrastructures at present and in times past.

Therefore, engaging the discourse of African youth anomie is arguably contextual. The context within which discourse appears is an issue that could be approached from both existing theories and realities. While the theories may come handy in explaining the currency of the situation, a single theory may seem to lack the potency for understanding the root causes of normlessness among African youth, and, perhaps the urgency. The sociological theory that significantly attributes decadence in a social system to drives of consanguinity and affinity (Merton, 
1947), and which are often less restrained by external factor is prevalent in the discourse. In contemporary Africa, the centuries-long severance of kits and kins may seem to render the natural attenuation of rigid theoretical appreciations of the peculiar situation invalid. The Balkanisation of contiguous social structure that occurred during the historic 'scramble' and its replacement with artificial boundaries for easy administrative purposes played a significant role. During the scramble, Africa lost the creativity of its young men and women, while the elders became hollow for lack, not want, of mentoring of the youth. As Rodney (1981, p. 161) pointed out, the European activities along the coasts and, later, hinterlands of Africa "was a direct block, in removing millions of youth and young adults who are the human agents from whom inventiveness springs. Those who remained in areas badly hit by slave-capturing were preoccupied about their freedom rather than with improvements in production".

Sociologically, two elements for understanding the roots causes of normlessness among elements of society have become very relevant to this study. Developed by Robert K. Merton towards the middle of the $20^{\text {th }}$ century, the two are indeed separated analytically, but they necessarily coalesce imperceptibly to explain the real-life situation of elemental groupings and their deviate behaviour. Merton (1938, p. 672) opined that the foremost essence of a group is to identify her 'culturally defined goals, purposes, and interests.' These goals, according to him, are the driving forces of the group, which they held high and proud as a matter of 'varying degrees of prestige and sentiment. Individuals within the group are expected to work for corporate and personal actualisation of these goals, more or less, and not betray it. The prevailing notion is that personal development is national development. The acceptable institutionalised manner for achieving these goals constitute the second phase that defines the social group. Merton (1938) argued that these guiding norms and 'moral imperatives' must be adhered by individuals even when they do not appear to be best efficiently or technically. In that regards, sharp practices, like theft, robbery, fraud, and corrupt practices, among others, are not permitted within the institutional framework. Merton, however, did not define the consequences awaiting an individual deviating from the defined cultural goals or cutting corners by bypassing the institutional norms, fraudulently or technically, in achieving the goals.

For most of Africa, the above suppositions would seem to capture the state and the plight of the youth, who are educated through the various media daily as the defined values of their respective societies. However, the defining means for achieving the values are not within their reach. Hence, It is no innuendo to state that exacerbation of the lingering governance crisis in Africa would continue, or gravitate towards producing failed states, should the demographically dominant youth continue to flounder within the collapse in societal values, especially in which morality gets relegated beyond manageable proportion in the society. Beyond the massive unemployment of youths, the dearth of responsiveness on the part of governments and lack of focus on a sustainable development plan in Africa, youth lack the independent capabilities for social engagements and their roles and involvement in political and governance processes have continued to suffer setbacks. Often, youth in Africa are denied of the autonomous representation except sanctioned by the adults, despite the demographic strength and increased access to information and communication technologies in favour of the youth. As Olaiya (2014) pointed out, the adults always predefine and hand down to the youth the role to play in political and governance processes. The author argued the youth "is hardly on their terms but those of the adults who bestride the socio-political and economic landscapes like the colossus". The critical mass of recycled adults and 'strong' individuals who wield a disproportionally high, if not total, commanding heights on the economies and politics: with the constant audacity to engage the resources with little or no resistance from the youth. Most often, therefore, the adults are the ones empowered with the available resources, which they use to manipulate the system with paltry employment and political duties for the youth.

\section{Pre-Atlantic slave trade and precolonial period: Mal-integration in African societies}

It is consistent with the narrative of slave trade to ascribe whatever horror of the illicit trading in human being as the horror against the youth since most of the slaves were young men and women, if not children. Lugards (1962, p. 384) revealed "the slave-trade and open dealing in slaves in British Africa takes the form of kidnapping, or purchase by trading caravans, especially of children" The point here is first to separate, not in the least absolve, colonialism from the slave trade. There is an attraction in African studies that tends to equate colonial Africa as though it coincided with the Atlantic slave trade era. They are worlds apart even though the state of lawlessness and atrophy occasioned by the two may appear the same. It is wrong to tag as precolonial Africa a time when the global clamour for African slaves was still ravaging all social, economic and political settings and rendered the geographical space alienated from her culture, heritage, jurisprudence and propriety. Canonical periods spanning the ancient and medieval eras - when "Law of Caesar on Municipalities" (44 BC) and "The Statute of Labourers" (1351) - till the $15^{\text {th }}$ to early $19^{\text {th }}$ centuries that witnessed the various treaties and compacts (Alcacovas treaty of 1479, Tordesillas treat of 1494, Madrid compact of 1495, Vitoria treaty of 1524, Treaty of Westphalia of 1648 , several slavery prohibition laws from 1780 to the Fugitive Slave Act of 1850 and African slave suppression treaty of 1863 in the US, among others) mainly between biggest slave nations in Europe such as Spain and Portugal, England, Germany Italy, and Belgium, could not for the discourse of Africa be tagged colonialism. "Different degree of expression" of colonialism may have "existed in almost all periods of world history", as Stuchtey (2011, 
p. 4) argued, the occurrences of banditry (local chiefs and foreign traders) selling and purchasing young ablebodied men and women across African continent could hardly fit neither what Wolfgang Reinhard (2008) referred to as "control of one people by an alien one" (Quoted in Stuchtey, 2011, p. 4) nor the be conceived as "a state that establishes an alien, colonial rule" (Stuchtey, 2011, p. 4). Shaw (1905, p. 408) wrote, "The earliest Greek historians speak of slaves capture... and the monuments of Persia and Ethiopia show that the enslavement of the Negro was a custom more ancient than any written record". Thus, for whatever it is worth, the pre-colonial Africa must refer to the pre-slave obsession time for black captives and how this could be determined should be left for further research by well-meaning archeologists and anthropologists.

The History channel reported that over 12 million young Africans were forcefully removed from their homelands as slaves from about 1525 to 1866 (Greenspan, 2019). The captives, their bewildered kindred left behind, were at the time subject of laws other than from their native authorities and custom. But for the steadfast defence put up by the Abolitionists in 1841 in favour of Sengbe Pieh, Gilabaru, Kimbo and 33 other young Africans who had committed two needless murders while fighting for freedom onboard Amistad in 1839, the Cuban slave traders, Jose Ruiz and Pedro Montes could have succeeded in taking the African to the destination sugar plantation (Greenspan, 2019). At the time of committing the murders, most the captives were in their early 20s together with teenage boys and girls and children (Jones, 1841; Thomas, 1997; Perry, 2014). Colonialism in Africa may, therefore, seem to have commenced when the German Chancellor Bismarck called the 1884 meeting at Berlin to partition Africa for the avoidance of colonial interests among European nations interested in African slaves. The logic is not as simple as thinking that one predates the other, the fact to consider is that one provided the template, and perhaps the temerity, for embarking on the other. It is hard admittedly to imagine a world where there existed no slave trade and, going by the records of resistance of Africans against it, whether colonialism in Africa would have been so profoundly successful. It is hard to surmise whether the Europeans who warred for the soul of Africa would have calmly partitioned Africa on a Berlin table without giving considerations for the natives. The idea is that the African society was already annihilated and weakened tens of centuries before colonialism. Whatsoever colonialism unleashes on Africa was made possible because the military agency of the youth had already been annihilated and replaced by that of the helpless adults.

The slave trade did not help the matter. Kingdoms were, or for insidious material gains allowed themselves to be played against one another, with raided Africans sold as "good merchandise in" European slave market, like "Hispaniola" (Shaw, 1905, 327). The brutal expeditions for negro merchandise reported in Shaw (1902, pp. 322347) had the blessing of constituted authorities and encouraged by European elites such as "John Hawkins, Sir Thomas Lodge, Mr. Gunson, ...Sir William Winter, Mr. Bromfield” from England axis; "Ericks and de Ruyter" from Dutch; a host of others such Portuguese, French, Danes, and Prussians to mention a few. The slave raiders operated much in the habit of the "Arab slave raiders", "assaulted the towns both by land and sea", touched natives house "being covered with dry leaves", "obtained the towns and put the inhabitants to flight" and took hundreds helpless "persons, men, women, and children" with active connivances of natives neighbours who also took close to thousands of fellow African as slaves (Shaw, p. 328). Indeed, Flora Shaw's apt quote from "Description of the Coasts of North and South Guinea", published in 1732 by Jean (or John) Barbot, a French historian and trader in West Africa for about twenty years, captured it all. The slave merchants comprising, among others

"The Portuguese...Prussians...Danes...Dutch treated the natives with arbitrary cruelty...it may well be said the Europeans have not dealt with them as becomes Christians, for it is too well known that many of the European nations trading amongst these people have very unjustly and inhumanly, without any provocation, stolen away from time to time abundance of the people, not only in this [one] coast, but all over...the histories of those times give an account of unparalleled violences and inhumanities committed [in Africa] by those insatiable [slave traders]" (pp. 324, 337-338).

Stated for umpteenth times, therefore, the slaves were sequestered away to culturally different places where their senses of being were non-existent. In that situation, it begs an important question whether such a situation and what Ekpo-Otu (2009) aptly called "wrongful and alien deconstruction" can exist within the parlance of the biological trait to deviant behaviour? Even after the repatriation of former slaves to different parts of Africa, following the stoppage of the trans-Atlantic slave trade, the former slaves from disparate origins were still so disoriented to carve identities of their own, not to say relate in biological manners. As Sawyer (2009) argued, such repatriation only added to the clusters of the group in those areas to create groups with new identities "associated with western concepts of justice and equality" like the Evolue of Guinea, Creole of Sierra Leone and Americo of Liberia. According to him, those who populate these groups lack collective identity, for the most part: their only connection was that they were former slaves from French, British and American political jurisdictions and rescued captives from various locations on the same journey of repatriation.

Granted that the history of Africa vis-à-vis the trans-Atlantic slave trade led to the untold derailment of sustainable development in the region (Rodney, 1981; Agbu, 2009), the specific impacts on African youth have continued to take its toll till date. Agbu (2009) discussed several adverse occurrences against African youth from 
the "colonial to contemporary times", although the phenomenon of the dispirited youths predates the estimation. The author argued that a crucial problem in today's Africa is that the youth face a bleak future, obviously from lack of planning process that slave trade fostered: a situation well engineered during the colonial and postcolonial periods (Ekpo-Otu, 2009). It therefore stands to reason, as Ndlovu-Gatsheni (2013, p. 135) argued, that the youth are product of history, after all "lawlessness and violence ruled the colonial [African] zones". The writer posited that Fanon (1968) who experienced "colonialism in his native country of Martinique and Algeria that became his second home" had submitted:

"The colonial world is a world cuts into two. The dividing line, the frontiers are shown by barracks and police stations. In the colonies, it is the policemen and the soldiers who are the official, instituted go-betweens, the spokesmen of the settler and his rule of oppression. [...] In the colonial countries, on the contrary, the policemen and a soldier, by their immediate presence and their direct action maintain contact with the native and advise him by means of rifle-butts and napalm not to budge. It is obvious here that the agents of the government speak the language of pure force. The intermediary does not lighten the oppression, nor seek to hide the domination; he shows them up and puts them into practice with the clear conscience of an upholder of the peace; yet he is the bringer of violence into the home and into the mind of the native" (NdlovuGatsheni, 2013, p. 130).

As Boon and Eyong (2005) also pointed out, the full-blown trafficking of Africans captives in manacles, otherwise known as slaves, has been effectively on course since the $14^{\text {th }}$ century "when the first contingents" of young able-bodied captives were taken to America to serve as labour on plantations, especially in places like Jamestown, Virginia, New Orleans, Louisiana and many others" (p. 6). Beyond repeating a menace already at the receiving end of wide condemnation since the $16^{\text {th }}$ century, there are contingent moral questions that resonate for today's anomie in African youth. Principally, apart from being manacled and shipped inside overcrowded vessels across a long voyage on the Atlantic, the slave traders, "from" mainly "Portugal and other European countries", tampered with the selfness and confidence of the young folks by presenting them first as standard merchandise for barter or auction. Several millions of fatal death occurred during the raids of the coasts and hinterlands for young men had preceded the journeys, and there were instances of rape and sodomy, on or witnessed by the young Africans, that unquestionably shaped their thoughts and capable of implanting the seed of immorality and disrespect for human lives. There are also reports that those who attempted escaping the horror, mainly the young of the slaves, are "given snake-beatings", which instils psychology of savagery.

As Zoetti (2020) rightly posited, enlisting violence to correct misdemeanours in youth could be counterproductive. According to the author, violent measures tend to "foster, rather than curb, youth offending and the violence committed by and against young citizens". However, the critical impact of slavery for this research relates to how African youth in their primetime, hitherto accustomed to organised and calm communal lives were suddenly whisked away for sale into foreign territories and cultural settings of zero bearings to neither their upbringing nor continued prospect. In the process, millions of energetic youth of working age were forcefully made to embark on what the local folktales called 'a journey of no return'. In the end, the 'fortunate' few that were not apprehended were not so fortunate. They lived in constant anguish of losing peer group members and the strains of confinement to the farthest of the hinterland with virtually no touch with the larger ancestral communities. In the end, the sacred tie between the young ones and traditional institutions lost its hold in terms of the rites of passage and moralisation. The situation led the youth to be more disrespectful and wary because of the accusations that the supposed traditional heads were the moles and intermediaries who pinpointed prospective youth to the slave traders for private gains. Finally, the slave trade brought untold hardship of war apart from the idea of illgotten wealth that passed from generations past to the present ones. War, more of the search for human captives than disputes, broke out en masse in Africa. The confusions emanating from the needless wars led to heightened security challenges, massively displacing young generations from their biological mentors and the fragmentation of the inherited civilisations.

The successor to the slave trade is colonialism. Colonialism involves the use of physical or mental force to subdue a society to accept foreign rules and the former accepting the establishment of economic, political and social control of the latter (Brett, 1973). Colonialism entails "the practice, the theory, and the attitudes of a dominating metropolitan centre, ruling a distant territory" (Said, 1993, p. 8). Colonialism brought about the bitter wars ever fought in African history (like the Kiriji War in South-Western Nigeria) through the creation arbitrary borders for their administrative expediency "done with utter disregard for the indigenous people, their histories or past animosities" (Boon \& Eyong, 2005, p. 8). In "The Oyo empire 1600-1836: A West African imperialism in the era of the Atlantic slave trade" Robin Law (1977) argued that expansionist missions of the Oyo Empire spanning about four centuries was in the real sense a conveyor belt for slave raids.

In essence, both slave trade and its offshoots - colonialism, imperialism and globalisation, relate effectively to produce the character of present-day anomie in African youth. As Boon and Eyong (2005, p. 6) argued, "governance in Africa before the arrival of the white man was centred around communal leaders who, as 
individuals or groups, excelled in various ways" by insisting on the moral commitment of the citizens to the wellbeing of the community and the "collective improvement of the people". For instance, the colonial rule that relegated any native law and custom as barbaric and repugnant to natural justice, equity and good conscience, as it is the case in former colonies of England, takes away the nurture instrument of the youth in the African ways, rightly or wrongly. Slavery and colonialism played pivotal roles in the general annihilation of the African space that progressively results in the modern anomie of her youth. Amadou-Mahtar M'bow, a one time Director-General of UNESCO captured the entire scenario in the preface to (Boahen, 1985, p. xxi-xxii) thus

"the slave trade, that 'endlessly bleeding wound', which was responsible for one of the cruelest mass deportations in the history of mankind, which sapped the African continent of its life-blood while contributing significantly to the economic and commercial expansion of Europe; colonization, with all the effects it had on population, economics, psychology and culture; relations between Africa south of the Sahara and the Arab world"

\section{Western education and the evolving scenario}

Was there a process for learning native to Africa, prior to slave trade and colonisation? Were Africans learning in established institutions, as there are teachers and students in today's European schools? Is there a 'Black African' civilisation that predated the 'White Africa'? The answers to these posers are certainly difficult to push: not for its mendacity but much more because the process for establishing the facts are firmly in the Europeanised educational system that the answer seeks to unravel. It may sound like pushing a conspiracy theory, or be quickly adjudged so, since African historiography, supposedly imaginary or at best grossly inferior, should commence as part of the imagination of European's Middle age, when 'Africa' was 'discovered'. Besides, early attempts to pen the history of Africa were dug up from personal memoirs, diaries and paperwork of those who came to dominate her, namely the Arab and the European slave traders turned colonisers. It may be deduced from the writings of Flora Louise Shaw (1905, p. 6) that what is relied upon and adamantly portrayed as African history is hardly "from original manuscripts, but chiefly from translations of Arab historians" that she later described as the forerunners of slave trading and colonialisation in Africa upon conquering Egypt in 638. Neither the Arab historians who wrote from perspectives of the assailants nor the Europeans who anchored on the former possess the integrity to write African history. Thomas Astley, writing in 1745, argued, "the author, who collects from others, is far from being exact" (Quoted in Law, 1982, p. 155). Besides, the unprovoked traders of African as slaves and colonisers have not shown necessary remorse by way of apology, or perhaps reparation, to be seen to have eschewed malice and the need to redact the wrongs deeds on their parts. It may well be presumed that the desire to undo the "idea of the [African] civilisations which have preceded our own [European's] in our lately acquired territories in the interior of West Africa, as Shaw (1905, p. 6, parenthesis insetrred) revealed, informed the historiographical picturesque to believe, As Amadou-Mahtar argued, "not so much of the paths actually taken by the African peoples as of those that the authors thought they must have taken" (Boahen, 1985, p. xx)

The progressive annihilation of African history, where her educational patterns and civilisations could be properly deciphered, would, therefore, not condone any other approach or methodology other the ones thought in England, Paris or Brussels. As Amadou-Mahtar M'bow wrote,

"the slave trade and colonization...bred contempt and lack of understanding and became so deep-rooted that they distorted even the basic concepts of [African] historiography" (parenthesis mine). Preface to Boahen (1985, p. xx).

However, established historians/anthropologists like Frobenius, Delafosse and Labriola have unearthed the existence of indigenous 'Black African' civilisation, which existed in the Ancient period, if not millennia before the slave trade and colonization of Africa (Boahen, 1985). There were established writings of African descent that contained sophisticated pattern for systematic learning. For instance, the Ifa divination that is widely canvassed to have originated in the Ancient era from Ile-Ife, the acclaimed cradle city of the Yoruba people mainly in southwestern Nigeria uses 16 odus (compendium), each subdivided into 16 to make 256, ikin (sacred object) and iroke ifa much like today's stylus, among other transcription materials (Clarke, 1939; Bascom, 1941; Pogoson \& Akande, 2011). There existed other languages of systematic sophistry such Dogon, Nsibidi, and Bambara. The world, perhaps the rampaging slave traders and European colonialists, wasted no time to truncate the systematic development of home grown educational system that could grow with the young men and women, learning and consolidating from mistakes and experiences. Instead, colonialists replaced the learning process with their foreign procedures, hook, line and sinker. The contemporary tendency in today's African youth is to acquire education by hook or crook appears to gather its root during colonisation when fresh African graduates began arriving back into Africa. Before and during the struggle for political independence, many Africans were sponsored abroad by the colonisers and Christian missionaries to acquire western education and upon returning were given plum jobs that immediately catapulted them to great heights. This strategy was adopted to placate Africans or dissuade the emerging force of Africanists from abandoning their struggle for a better life afforded them by western education. Thus acquiring western education was regarded as a guarantee of success. As much as education in Africa is 
desired as elsewhere, Ekeh (1975) argued, the African bourgeois class subverted this need in a curious way.

Contrary to what obtains in other climes where educational accomplishment on provides opportunities to be successful, such attainment is instead that assurance of success in the colonial and postcolonial Africa. The link to anomie of using 'high sounding' certification as a standard for personal progress is not far fetched. Few will dispute that making such avenue to automatic success invited today's syndrome of 'Chicago-gate' and 'Toronto' certificate racketeering as well as the pervasive examination sharp practices. Thus, the heightened criminal tendencies among the youth directly reflect the emphasis on success as an end in itself without watching over the methods for accomplishing the targets. In such societies as African states have thus become, the emphasis on paper qualification leads to what Merton (1938, p. 681) tagged "prestige-bearing success", which "tends to eliminate the effective social constraint over means employed to this end". Ultimately, it then becomes "[T]he-end-justifies-the-means" as "a guiding tenet for action when the cultural structure unduly exalts the end" notwithstanding the means, a direct product and manifestations of the corrupt practices in the larger societies.

Corruption is not, and cannot be, peculiar to Africa. Classic and contemporary scholarships have established that democratisation and economic liberalisation have the capacities to jointly or severally repress corruption to the barest minimum (Smith, 1776; Schumpeter, 1918 (1991); Moore, 2004; Diamond, 2008; Kaufmann, Kraay \& Mastruzzi, 2010; Kubbe \& Engelbert, 2018; Olaiya, 2020). The continued prevalence of corrupt practices in the Americas, Asia, Africa, and other regions of the world, despite "the third of democratisation and concurrent economic liberalization" obfuscate "expectations" or, perhaps, proved the liberal bookmakers wrong. Corruption is manifesting in different shades and patterns in all parts of the globe (von Soest, 2013, p. 7). In the US, the appointed special prosecutor, Robert Mueller, reported that the Internet Research Agency (IRA) based in St. Petersburg and the Russian Federation's Main Intelligence Directorate of the General Staff (GRU) interfered and did skewed the 2016 presidential election in favour of incumbent, President Donald Trump (See Robert Mueller's Report Vol. 1, 2019). That President Trump still remains in office till date, despite the conviction of key members of Trump's campaign organisation such as Michael Cohen, Michael Flynn, Richard Gates, William Samuel Patten, Alex van der Zwaan, Richard Pinedo, Carter Page, Paul Manafort, and Roger Stone, George Papadopoulos, among others, convicted for committing inter alia "crimes by colluding with Russian government officials with respect to the Russian government's efforts to interfere with the 2016 presidential election" (Robert Mueller's Report, 2019 , p. 11) smacks of condoning corruption in US politics and is instructive that the US is not insulated from corruption.

However, the colonial experiences in Africa persuade us to tinker with the belief that perhaps the current pervasiveness of corruption in Africa could have been averted considering the primordial modes of governance and accountability existing before colonisation. Ellis and Shaw (2015) recorded how companies owned by colonial masters were ripping money away illegally using the crooked method of over-invoicing. No one has argued more vociferously to establish the colonial root of African corruption than Ekeh (1975) in his epic paper titles "Colonialism and the Two Publics in Africa: A Theoretical Statement". The writer drew a remarkable distinction between the "civic public", which is rooted in the cultural settings of precolonial Africa, and the primordial public, which millennia of slave trading and centuries of colonial rules foisted on postcolonial Africa. According to him, the primordial public functions on strict moral codes and sentiments associated with private property, which nevertheless impinge on the public interest and attitude. On the other hand, is the civic public that operates mainly in the public realm without the same sentimental attachment to moral codes as identifiable with modern politics and government institutions of postcolonial states.

Ekeh argued that the primordial public is entirely devoid of corrupt practices even though the educated elites in government service operate in the two realms simultaneously. Strangely, however, the primordial elements encourage the same individual to carry out the corrupt practices in the civic realm and "he may risk serious sanctions from members of his primordial public if he seeks to extend the honesty and integrity with which he performs his duties in the primordial public to his duties in the civic public by employing universalistic criteria of impartiality" (Ekeh, 1975, p. 110). The constitutive effect of this is that modern African societies pass on to her generations a culture of graft in the civic realm. As can be expected, the private realms, in which the primordial public operate are no longer spared.

Corruption is a problem for which the anomie of African youth, and ditto the governance crisis could be explained. A public official is expected to embezzle and misappropriate public fund in favour of his primordial base, just as the colonial officials were perceptively operating and syphoning resources from the colonies to their homelands. For instance, the colonial Governor "enjoyed to the full the outward trappings of power, living in an imposing palace, driven in large limousines flying the flag, reverenced by all, and on ceremonial occasions dressed in a cocked hat and plumes and a quasi-military uniform" (Crowder, 1987, p. 5). Aboagye and Hillbom (2020) provided archival evidence that revealed how the African members of the Legislative Council unsuccessfully moved against the corrupt practices prevalent in Gold Coast (now Ghana) among colonial officials. In their words, the officials operated with reckless abandon, "gallivanting the finances of the" colony; lavishing and corruptly 
inflating construction sums by "building palatial bungalows" across the colony at the bloated "rate of $£ 130,000$ a year"; and appointing their European kits and kin as government "officials in large numbers" beyond the administrative need and capacity of the colony. Hence, the colonisation of Africa introduced the fleece attitudes to public office that the youth watched with horror at first and later with the resolve to "join them, since you cannot beat them".

However, the nationalists that eventually inherited power more than aggravated the matter. As Frantz Fanon argued, the postcolonial attitudes of the so-called nationalists comprised "quite simply... [to] transfer into native hands... those unfair advantages which are the legacies of colonialism", and "has nothing to do with transforming the nation; it consists, prosaically, of being the transmission line between the nation and a capitalism, rampant though camouflaged, which today puts on the mask of neo-colonialism" Quoted in Mkandawire, 2005, p. 20). Pierre Mille, a renowned writer on colonial affairs, underscored the colonial roots to corruption in West Africa when he described Senegal as a 'rotten borough' where sacks of rice and five-franc pieces were used by the Europeans to buy African votes (Pierre, 1901, p. 67). Also, Fosu (2009, p. 21) argued that immediately after independence, though political institutions replaced colonial institutions, "yet, the resulting political practices were only a shadow of these inherited institutions." The author stated that, much like their departed European colonialists, any forms of opposition were often inundated with the same vehemence, if not more. Internal checks and balances or devolution of powers were frowned at "to maintain the centrality of the executive branch of government." In the ensuing milieu, executive action undertaken in self-interest could hardly be questioned let alone controlled. He instructively concluded that regrettably, the interests of the new leaders were most often than not self-motivated and hardly in tandem with that of the general populace. Maclure and Denov (2006) traced the root of African economic woe from the colonial time to successive and current governments who imbibed the colonially bestowed spirit of corrupt practices. He argued prosaically that:

"With its legacy of slave resettlement, colonialism, and post-independence governance that served mainly to enrich a kleptocratic urban elite, Sierra Leone was integrated into the world system in a way that ruined its economic potential, marginalised and impoverished the vast proportion of its mainly rural population, and generated extensive antagonism against those who dominated the country's increasingly fragile 'shadow' state" (Maclure and Denov, 2006, p. 120)

\section{Governance implications of youth anomie in Africa}

As earlier discussed, anomie implicates the political governance of Africa in many ways. As Frankman (2004) however argued, "dispirited youth" left behind in the "collective construction of a democratic global order" mostly unemployed or forced into "dead-end jobs at rock bottom wages" - and inadvertently packaged in "crime and punishment" abound in all continents (pp. 25, 152-153). Africa's case is only peculiar for the historic sequestration of youth from primordial ties to foreign dictates from the slave trade era till date. There are sympathetic appeals on the ground that the case of Africa is only being over-celebrated by the Western media. Lavender (2011) argued that the continued conscription of African predicaments into the historical past is, in fact, an extension of the original "colonial representations of parts of Africa as a "Heart of Darkness" being "carried over into contemporary tropes about African political and societal chaos". Such optimistic positions would hardly fathom Kaplan's generational sequestration thoughts into the arithmetic of today's chaotic Africa. Lavender (2011, p. 3) insisted that the down-to-earth position of Frankman (2004), Kaplan (1996), Mkandawire (2005), Abbink and van Kessel (2005), among other things, are a part of the conspiracy theory and Western media's misrepresentations that "are dominated by negative images of young militants in civil conflicts, and of threatening young men in overcrowded" and that the theses upon which the claims are grounded rely on "some questionable evidence" that tend to be "coloured by emotionally charged images of angry young men from the global South". The writer however submitted that the African youth have lost their "positive energy" due to "lack of practical opportunities" leading, among others to "breakdown in the sense of youth as a meaningful transition period to adulthood. With fewer and fewer job opportunities, accompanied by other forms of economic failure and accelerating urbanisation, many young people were increasingly unable to find ways to support their livelihoods" (Lavender, 2011, p. 3).

The pessimists are more in touch with the realities, notably the conspiracy theorists on colonialism in Africa, than the optimists. As Merton (1957, p. 682) pointed out, coordination is essential to deter deviant behaviour. According to the author, a developing society must institute measures for "coordinating the means-and-goals phases of the social structure", as there can be no doubt that "lack of such coordination leads to anomie" (Merton, 1938, p. 682). There social-economic and political foundations have been affected by this lack of coordination, which in turn is passed across to the youth within the African societies. Olaiya (2014) argued that the dearth of sustainable ideas from which youth can be nurtured began during the colonial era. The writer pointed out that the desperate political stratagem of the colonial masters to gain the reins of Africa during and after the 'scramble' for Africa could not have objectively considered the fate and future of the youth not to talk of mastermind and prepare 
for today's youth bulge averaging $60 \%$ in the continent. The process of mal-integration then became exacerbated as the post-independent leaders who took over the rein of government only continued in the same fashion, preferring to rule for the time rather than for future. The youth in the modern States (former colonies) of Africa are, therefore, a bunch of unfortunate victims in a loose governance history. Thus, it is that colonial past that provided (or failed to provide) the spectrum of morality capable of insulating the youths against the festering anomic spree predominating in daily lives and politics, as well as bequeathals to the youths.

For instance, the degrading level of poverty in Africa is palpable in the ordinary sense of it, and this has been on the increase since the turn of the last century. Drawing empirical facts from Ile-Ife in Nigeria, Torimiro (2009) argued, youth were and still are engaged and exploited in hazardous economic activities. He submitted that the situation in Ile-Ife, a cosmopolitan city in Nigeria, is a vivid representation of happenings in most of Africa and is not likely to stop. There is, therefore, no gainsaying the fact that poverty contributes to deviate tendencies of the youth than any other factor. Merton $(1938$, p. 681) established that poverty or limitation of opportunity or the ofttouted "poverty in the midst of plenty" could not suffice "to induce a conspicuously high rate of criminal behaviour", but constitutes a catalyst for deviant behaviour. In his epic book entitled Contemporary sociological theories, Sorokin (1969) argued that the poor have not tended to show more proclivities to commit crime much more than the rich and neither do richer countries record fewer crimes than developing countries. Perhaps noteworthy it is that the advent of the industrial revolution in the North and the concomitant economic progress may not have translated to a decrease of crime rate, as Sorokin (1969) opined, for reasons that the phenomenon eluded the youth of Africa who constituted the most extensive and growing pool of youth. Despite the sociological differences in the study areas and circumstances of Merton (1938) and Sorokin (1962), the case of Africa varied remarkably in social significance and history. Whereas, Merton (1938) and Sorokin (1969) wrote about societies that never experienced a foreign rule that depleted her resources and simultaneously imbibed the orientation of social abuse and violence, sequestrating the bulk of innocent youth from their parentages and cultural background as was the case of Africa. Hence, even though crime and poverty relate linearly, the tendency for such a result is more prevalent in Africa than the steadily growing social structures of the advanced societies, which witnessed little or no culture shocks.

How youth (are) engaged in politics and as a collateral instrument for aggression or defence against opposition also followed the colonial patterns. It could be irrefutable that the warring parties of the WWI and WWII involved colonial subjects and resorted to drafting youths from their respective colonies into the wars. In several ways, youths are co-opted in Africa into mainstream politics, but the ultimate aim is not always in the real interest of the youth. In Nigeria for instance, as Olaiya (2014) pointed out, there is always the "youth wing of the mainstream parties, and quite often these youth wings become a kind of pseudonym for foot soldiers or political thugs" (pp. 4, 9). The essence is not to meaningfully engage the youth in a systematic and consciously planned political leadership but to permanently protect the existing hegemony of the ruling class composed mainly of adults. The methodology often utilised also calls for scrutiny, most notably as it tends to fester the existing normlessness prevalent among the youth. As Oruwari and Opuene (2006) have established, the exploitation of youth for violence and pseudo-nationalist struggles in neo-colonial Africa is no more news. Maclure ad Denov (2006) wrote that in Sierra Leone alone, the adults drafted approximately 40,000 teenagers as fighters in the decade-long civil war. One year after independence from Portugal in Mozambique, Seibert (2003) recounted how adults regularly organise raids to kidnap young men for military service and forcefully recruited children in the 1976 and 1992 civil war between the ruling Liberation Front of Mozambique (Frelimo) and Mozambican National Resistance (Renamo). In the aftermath, about $33.3 \%$ and $60.4 \%$ fighters of Frelimo and Renamo respectively were children under 18 years of age (Seibert, 2003).

Moreover, despite opinions of scholars that youth exploitations and participation in criminality and violence have precolonial antecedents, such contribution could pale considering the enormous social and economic magnitude of unbridled attacks and force employed by colonial imperialists to effect a systematic take over of most territories of Africa. Also, the oft-cited transfer of erring youth to neighbouring communities was meant to rehabilitate a rebellious youth and correct the ills of the society NOT the kind of 'wrongful and alien deconstruction' of human merchandising (Ekpo-Otu, 2009: 22) witnessed in the slave era and the colonial states of Africa.

\section{Socio-economic and political manipulation of African youths}

In his classic work entitled "Africa in the World: A history of extraversion", Bayart (2000) documented bundles of colonial activities across the continent of Africa that precipitated the present quest for money among the youth. The global culture of celebration of capital acquisition tagged 'globalisation' could not be divulged from the blinding 'dollarisation' that presently engulfs Africa. As Bayart (2000) argued, the "young diamond diggers of Balundu, on the border between Congo-Kinshasa and Angola" would not conceive such illicit monetary gain from illegal mining as anti-social, since such diamond digging is "congruent with a 'dollarisation' of the imagination" (p. 240).

Moreover, gradually shifting focus on African youth as victims of war, pestilence, violence, and poor 
governance to youth as constituting security and stability challenges is gaining momentum to the detriment of their plights. The protagonist of such idea premised that youth bulge coupled with rapid unemployment and urbanisation would necessarily constitute a keg of gunpowder if not correctly managed. While this assumption may not be mostly untoward, it must be advocated with care. The youth bulge is not a problem in itself; it is the mismanagement, most notably where urbanisation pooled them together, that is cataclysmic. Historically, the youth have constituted themselves as agents of positive change on the shores of Africa. Olaiya (2014) wrote that the youth participated decisively in the fighting not only colonialism in the continent but also against apartheid in South Africa, the rampaging militarism that engulfed Africa after independence, and recently in the enthronement of democracy. The author argued that the years of labour without rewards have seemingly toughened the youth that they almost could be regarded as a threat rather than the saviour they had constituted. Olaiya (2014) averred that the fate of the youth appeared no better than during colonialism when colonial masters dealt in them as slaves and subjected them to untold hardship and mean work conditions. The author pointed out that child labour is in agricultural farms in notable West African states for a take-home that cannot take them home contrariwise to the volume of the labour rendered. Olaiya $(2014$, p. 8) stated "in rubber plantations in Cameroon, a rubber tapper is expected to tap" over "550 trees of varying diameters, collect all the latex in an" eight-hour "working day for a wage equivalent to 1.39 Euros".

Besides, the civil wars in African states such as Nigeria, Liberia Sierra Leone Angola and Cote d'Ivoire, the genocide in Rwanda, Sierra Leone and conflicts of succession in nearly all African States including Guinea, Mali, Togo have all raised the bar of normlessness in African youth. In all of these, the tools have always been a youth, who are employed and conscripted by the adults to carry out the dastardly acts on the field. In most of the conflicts, the adult purveyors stay far off, tipping the young one into the nucleus of the battle lines. Apart from the fact that these battle-field educated youth were left to cater for themselves in the aftermaths of the wars, their accustomed ways of life - of a looting spree, wanton arson, rape, cannibalism, and other war crimes — would not be objectively expected to fizzle away within a short while. Thus, despite helping to instigate and being the main participants in momentous 1990s democracy revelation, which pioneered in the Republic of Benin, resulting in the transition to multiparty civilian rule, the agent of change was left holding the baby. Sadly, the events went by in all the liberated states without a systematised and decisive programme to rehabilitate the youths who did the yeoman's job.

Economically, the new world order of the capitalist economy has not been friendly to Africa, nay African youth. Capitalism was uncritically introduced into African economies with no one factoring the demographic strength and critical conditions of the youth into the mechanisms. For one, the need to maximise production and minimise cost put a more substantial moral and physical burden on the youth who were already used to the traditional, seasonal and manual agriculture. For another, stable subsistence economies became gradually extinct in place of specialised production and accumulation of surplus farm produce. Scholars of African development studies extraction (Amin, 1974; Oliver \& Atmore, 1967; Mkandawire, 2010) instructively divided Africa into three groups, in line with how colonialism integrated colonial Africa into European economic order. The first related to cash crop economies from mainly West Africa (Benin, Burkina Faso, Cameroon, Côte d'Ivoire, The Gambia, Ghana, Guinea, Guinea-Bissau, Mali, Mauritania, Niger, Nigeria, Senegal, Sierra Leone, Tanzania, Togo, and Uganda, among others) where monopsony institutions exploit peasant farmers with incredible notoriety on behalf of the colonial government. The second were mainly countries of the Congo Basin (Congo Kinshasa, Congo Brazzaville, Gabon, Central African Republic, Rwanda and Burundi, among others) where private concerns obtained access to vast land for mechanised farming and mining from colonial powers. Finally, the third category comprised mainly East and Southern African colonies (Angola, Botswana, Kenya, Lesotho, Madagascar, Malawi, Mozambique, Namibia, South Africa, Swaziland, Zambia, Zimbabwe, among others) with 'labour reserve' and 'wage economy'. Nevertheless, a common line across the three groups is the exploitation and denigration of the labour, mainly youth, through the payment of pittance for incommensurably laborious and forced task, and high fatality rate. As Rodney (1990, pp. 343-361) argued,

"undisguised forms of forced labour and barely disguised forms of slavery were prominent aspects of the entrenchment of the colonial economy in Africa... Wages were kept abysmally low. Upward trends were resisted; ... wages were depressed or allowed to lag behind commodity prices. Settlers and other resident Europeans and the managers of foreign enterprises combined to keep wages low and to keep labour semi-feudal through the issue of work-cards which severely limited the freedom to shift labour from one employer to another".

Besides, expanded production in Nigeria, Ghana, and other west African colonies began to exert more working hour, mainly from the youth. Also, diversified farming in the Congo Basin yielded way for mono-cultural farm produce that ran youth out of employment livelihood otherwise than to join the new trend. It is to be noted that, in the process, the youth lost the large volume of knowledge of subsistence crops passed from generation to generation. The land tenure system also changed dramatically in absolute contradictions to what the youth are accustomed to in precolonial Africa. Before colonisation, ownership of land was based on "tribal states or empires, organised along, unwritten cultural traditions of succession", in which a youth naturally inherits good portions of 
arable land for agricultural purposes. Thus, land ownership suddenly became merchandise for financial transactions. Finally, the colonial companies effortlessly outclassed local farmer with jumbo capital and megaproduction of 'cash crops'. The scenario ushered in a rush for wage jobs, destroying the complex system of communal farming, like the aaro and owe (mutual assistance benefitted and reciprocated in farms) in Yoruba traditional societies, and forcing the youth to 'shop' for jobs. Boon and Eyong $(2005$, p. 11) argued "the outcome is a precarious condition as the formerly self-sufficient people of Africa now sell their [land and] labour to western companies to eke a living". The precarious situation is more pronounced, as Boon and Eyong (2005) argued "in the sense that these former landowners cannot determine the price of their labour or the world market prices of their produce, and neither do they have the power to determine their conditions of work" (p. 12).

\section{Conclusions}

Nowhere else is the definition of 'youth' more at large than in Africa. This could be due partly, as the existing body of evidence revealed, to their roles as antagonists of oppression since the colonial times that have always pitched them against the authorities of the day. However, the critical role in the struggle for freedom in Africa cannot be overemphasised. Gyampo and Obeng-Odoom (2013) stated that the youth participated actively in the development drives that produced today's Africa since the colonial era. The United Nations (2019) considered the youth as anyone within the age range of 15 and 24. In Africa, however, the reality of this definition is impotent. The upper age range of youth ranges from 30 in Nigeria and 35 in Sierra Leone and Rwanda. The broader ranges of Africa is realistic because most persons of age 15 and 24 lack self-determination - in most cases they are still in school or under apprenticeship or unemployed. For this study, therefore, the submission of Hilker and Fraser (2009) appears handy. According to the authors, "youth is better understood as a transitional stage in life between childhood and adulthood, rather than as a rigid construct based on age" (Hilker \& Fraser, 2009, p. 9). Howsoever the definition goes, the fact remains that the African population is youthful.

Existing evidence also revealed that the youth constituting about $60 \%$ of the total population of Africa comprises one of the most marginalised social groups. In an attempt to redress the situation, the $7^{\text {th }}$ Ordinary Session of the Assembly of the African Union adopted the African Youth Charter in Banjul, The Gambia, on July 2 2006, with a wide-ranging commitment towards "promotion and protection of the rights of the youth". Article 10 of the Charter is devoted to the rights of the youth in development. It stipulates that state parties must protect and promote the right of youth to social, economic, political and cultural development as well as the involvement and leadership of youth programmes by young persons and youth organisations, among others. Besides, article 11 of the Charter, which emphasises youth participation in active politics, declared "every young person shall have the right to participate in all spheres of society". Properly managed and followed, the Charter could perhaps gainfully involve the youth in the political engineering of the nations. Thus, all state parties need do is commit themselves to take measures that promote active youth participation in political and economic processes to enhance the institutional capacity of the youth.

Fortunately, the 2006 African Youth Charter has been ratified by more than 15 AU member states and were currently in force. Twenty-three countries have ratified the African Youth Charter. However, the irony here is that in Africa today, one of the most marginalised social groups in the democratisation process is the youth, yet the AU has committed to redressing this imbalance through relevant protocols and charters. This reality points to the gap between the development of the normative framework on the one hand and domestication and application of these instruments at the country level on the other.

Amongst others, significant challenges are facing African countries as a result of weak institutional capacity of states and youth formations; a yawning gap between existing normative frameworks and policy practice at the national level; inadequate financing for youth empowerment; tokenism towards youth empowerment and political manipulation of youth especially during election periods and the overall mismanagement of diversity leading to election-related political violence with devastating consequences for Africa's development, governance, peace and security of which the youth bear the greatest brunt. There is, therefore, the need to halt the general trend whereby ratified frameworks are never fully domesticated and implemented. The socio-economic conditions of the African youth need to improve for youth to be active and positives contributors in democracy building, electoral processes, and the effective management of diversity.

It is crucial to overstate the need for revolutionary dimensions of social change inherited and persisting since the colonial era. There is no gainsaying the fact that ideas and opportunities in modern Africa are monopolised by few but influential adults and their cronies. Nearly a century since colonisation ended in Africa, the opinion expressed by Waller (2006) about the tight grip of adults onto the socio-economic and political resources, much to the alienation of the youth, continues to hold sway. According to him, the elders who controlled "most of the cards throughout the colonial period' still call the shot, either directly by themselves or their offspring or allies... they controlled marriage, access to land and livestock, education, employment, and also the social knowledge that the young would need to survive and prosper" (p. 87).

In the event of historical annihilation of youth in Africa's mainstream political processes and economic 
leadership and their implications on economic emancipation of the continent the anomie of the youth in resulting to sharp practices appears to be inevitable. Moreover, perhaps it behoves to argue that the present state of the continent's economies and development doldrums is not far-fetched considering the exclusion of large pool of young people at their prime as though they represent a problem rather than engage them meaningfully as a source of enrichment to the ailing economies. It is therefore expedient that Africa refashions itself in the 21 st century since the contribution of the youth in a continent with the most youthful populations in the world remains critical to the developmental possibilities. There is no doubt that their continued denigration since the colonial and postcolonial times can lead to an expressive culture of deviant behaviour and volatile politico-economic environment. Whereas they represented a significant force for social and political change, they can also be purveyors and victims of the complicated intrigues that characterise the psychology of doing business with/in Africa.

\section{References}

Aboagye, P. Y., \& Hillbom, E. (2020). Tax bargaining, fiscal contracts, and fiscal capacity in Ghana: A long-term perspective. African Affairs, https://doi.org/10.1093/afraf/adaa004

Abbink, J., \& van Kessel, I. (2005). Vanguard or vandals: Youth, politics and conflict in Africa. Leiden \& Boston: Brill.

Adebanwi, W., \& Obadare, E. (2010). Introducing Nigeria at fifty: The nation in narration. Journal of Contemporary African Studies, 28(4), 379-405.

Adejumobi, S. (2011). Introductory address at the Pre-Eighth African Governance Forum (AGF-VIII) multistakeholder Policy Dialogue on "Youth Empowerment, Elections and the Management of Diversity in Africa, Accra

African Youth Charter. (2006). Adopted by the Seventh Ordinary Session of the African Union Assembly, Banjul, The Gambia, July 22006.

Agbu, O. (2009). Children and youth in the labour process in Africa. Dakar - Senegal: Council for the Development of Social Science Research in Africa (CODESRIA).

Amin, S. (1972). Underdevelopment and dependence in black Africa-origins and contemporary forms. The Journal of Modern African Studies, 10(4), 503-24.

Bandura, R., \& Hammond, M. (2018). Introduction: Nigeria case study. In R. Bandura \& M. Hammond (Eds.) The future of global stability: The world of work in developing countries. Center for Strategic and International Studies (CSIS).

Banks, N. (2006). Youth poverty, employment and livelihoods: social and economic implications of living with insecurity in Arusha, Tanzania. Environment and Urbanisation, 28(2), 437-454.

Bascom, W. R. (1941). The sanctions of Ifa divination. The Journal of the Royal Anthropological Institute of Great Britain and Ireland, 71(1/2), 43-54.

Bayart, J. F. (2000). Africa in the World: A history of extraversion. African Affairs, 99, 217-267. DOI: 10.1093/afraf/99.395.217.

Bird, R. M., \& Zolt, E. M. (2005). Rethinking redistribution: Tax policy in an era of rising inequality: Redistribution via taxation: The limited role of the personal income tax in developing countries. UCLA Law Review, 52(6), 1627-867.

Boahen, A. A. (ed.) (1985). General history of Africa vol vii: Africa under colonial domination 1880-1935. Heinemann/UNESCO.

Boon, E. K., \& Eyong, C. T. (2005). History and civilisations: Impacts on sustainable development in Africa. In Regional Sustainable Development Review: Africa. Oxford: Eolss Publishers. Retrieved August 27, 2012, from <http://www.eolss.net>.

Brautigham, D. A. \& Knack, S. (2004). Foreign aid, institutions, and governance in sub-Saharan Africa. Economic Development and Cultural Change, 52(2), 255-285.

Brett, E. A. (1973). Colonialism and underdevelopment in East Africa: The politics of economic change 19191939. New York: NOK Publishers

Burgess, G. T., \& Burton, A. (2010). Introduction. In A. Burgess \& H. Charton-Bigot (Eds.), Generations past: Youth in East African history (pp. 1-24). Ohio: Ohio University Press.

Callaci, E. (2011). Dancehall politics: Mobility, sexuality, and spectacles of racial respectability in late colonial Tanganyika, 1930-1961. The Journal of African History, 52(3) (2011), 365-384.

Chenping, C. (2019). The influence of social network on youth political expression. Canadian Social Science, 16(2), 25-30

Clarke, J. D. (1931). Ifa Divination. The Journal of the Royal Anthropological Institute of Great Britain and Ireland, 69(2), 235-256.

Crowder, M. (1987). Whose dream was it anyway? Twenty-five years of African independence. African Affairs, 86(342), 7-24. 
Diamond, L. (2008). The spirit of democracy: The struggle to build free societies throughout the world. Henry Holt and Company, New York.

Ekeh, P. (1975). Colonialism and the two publics in Africa: A theoretical statement. Comparative Studies in Society and History, 17(1). 91-112. Downloaded from Stable URL: http://links.jstor.org/sici?sici

Ekpo-Out, M. U. (2009). Getting them young: Child labour in Ikot Ekpene from aisepi historical perspective. An O. Agbu (Ed.) Children and Youth in the Labour Process in Africa. Dakar - Senegal: Council for the Development of Social Science Research in Africa (CODESRIA), pp. 21-34.

Ellis, S., \& Shaw, M. (2015). Does organized crime exist in Africa? African Affairs, 114(457), 505-528. DOI: 10.1093/afraf/adv035

Fanon, F. (1986). The wretched of the earth. New York: Grove Press

Fosu, A. K., (2009). Understanding the African growth record: The importance of policy syndrome and governance. United Nation University-World Institute for Development Economics Research (UNU-WIDER) Discussion Paper No. 2009/02

Frankman, M. J. (2004). World democratic federalism: Peace and justice indivisible. International political economy series, Great Britain: Palgrave Macmillan

Greenspan, J. (2019, February, 6). The Amistad slave rebellion, 175 years ago. Available at https://www.history.com/news/the-amistad-slave-rebellion-175-years-ago

Gyampo, R. E. V., \& Obeng-Odoom, F. (2013). Youth participation in local and national development in Ghana: 1620-2013. The Journal of Pan African Studies, 5(9), 129-50.

Hilker, L. M., \& Fraser, E. (2009). Youth exclusion, violence, conflict and fragile states. Published by Social Development Direct

Jones, Q. (1841). Argument of John Quincy Adams, before the Supreme Court of the United States: in the Case of the United States, Appellants, vs. Cinque, and Others, Africans, Captured in the schooner Amistad, by Lieut. Gedney. https://avalon.law.yale.edu/19th_century/amistad_002.asp

Kaplan, R. (1996). The ends of the earth: A Journey to the frontiers of anarchy. Vintage

Kaufmann, D., Kraay, A., \& Mastruzzi, M. (2010). The Worldwide Governance Indicators: Methodology and Analytical Issues. World Bank Policy Research Working Paper No. 5430. Available at SSRN: https://ssrn.com/abstract=1682130.

Kubbe, I., 7 Engelbert, A. (2018). Corruption and the impact of democracy. Crime, Law and SocialChange, 70, 175-178. DOI: $10.1007 / \mathrm{s} 10611-017-9732-0$

Lavender, G. (2006). African youth as a source of hope and ingenuity: The role of the United Nations in engaging young people to help overcome poverty in Africa. Paper downloaded online 22-09-2018.

Law, R. (1982). Jean Barbot as a Source for the Slave Coast of West Africa. History in Africa, 9, 155-173.

Lugard, F. (1962). The dual mandate of the British in tropical Africa. Edinburgh \& London: William Blackwood and Sons.

Maclure, R., \& Denov, M. (2006). I didn't want to die so i joined them: Structuration and the process of becoming boy soldiers in Sierra Leone. Terrorism and Political Violence, 18, 119-135. is iepiDOI: $10.1080 / 09546550500384801$.

Merton, R. K. (1938). Social Structure and Anomie. American Sociological Review, 3(5), 672-682 Stable URL: http://www.jstor.org/stable/2084686

Merton, R. K. (1957). Social theory and social structure. Glencoe: The Free Press

Mkandawire, T. (2005). African intellectual: Rethinking politics, language, gender, and development (Ed.). CODESRIA.

Mkandawire, T. (2010). On tax efforts and colonial heritage in Africa. The Journal of Development Studies, 46(10), 1647-1669. DOI: 10.1080/00220388.2010.500660

Moore, M. (2004). Revenues, State Formation, and the Quality of Governance in Developing Countries. International Political Science Review / Revue Internationale De Science Politique,25(3), 297319.

Mueller, R. S. (2019). Report on the investigation into Russian interference in the 2016 presidential election Volume I of II. Available at https://www.justice.gov/storage/report.pdf

National Youth Service Corps (NYSC) Act, Cap. 84, Laws of the Federation of Nigeria (2004)

Ndlovu-Gatsheni, S. J. (2013). Coloniality of power in postcolonial Africa: Myths of decolonization. CODESRIA.

Olaiya, T. A. (2014). Youth and ethnic movements and their impacts on party politics in ECOWAS member States. Sage Open, 4(1), 1-12. DOI: 10.1177/2158244014522072

Olaiya, T. A. (2016). Proto-nationalisms as a sub-text for the crisis of governance in Nigeria. Sage Open, 6(2), 113.

Olaiya, T. A. (2020). Regulatory mechanisms and incentives nexus in taxation and governance of West African economies. Article accepted for resubmission and review in International Journal of Public Administration.

Oliver, R. A., \& Atmore, A. (1967). Africa since 1800. London,: Cambridge University Press. 
Oruwari, Y., \& Opuene, O. (2006). Youth in urban violence in Nigeria: A case study of urban gangs from Port Harcourt. Niger Delta Economies of Violence working paper No. 4. Berkeley: Institute of International Studies - University of California.

Perry, J. D. (2014, July, 2). Who were the Africans who revolted aboard the Amistad? Available at http://www.tracingcenter.org/blog/2014/07/who-were-the-africans-who-revolted-aboard-the-amistad/

Pierre, M. (1901). The black vote in Senegal. Journal of the African Society, 1, 64-79.

Pogoson, O. I., \& Akande, A. O. (2011). Ifa divination trays from Isale-Oyo, Cadernos de Estudos Africanos, 21, $15-41$.

Rodney, W. (1981). How Europe underdeveloped Africa (Revised edition). Howard University Press.

Rodney, Watter. 1990. The colonial economy. In A. A. Boahen (Ed.), General history of Africa Vol. VII: Africa under colonial domination 1880-1935 (pp. 332-350). California: UNESCO, Heinneman.

Rotberg, R. I. (2007). As Nigeria goes, so goes Africa. In Nigeria: Elections and continuing challenges. Council on Foreign Relations.

Said, W. E. (1993). Culture and imperialism. Knopf/Random House New York.

Schumpeter, J. (1991). The crisis of the tax state. In Joseph R. Swedberg (Ed.), The economics and sociology of capitalism. Richard Swedberg. Princeton: Princeton University Press. First published in 1918.

Seibert, G. (2003). The vagaries of violence and power in postcolonial Mozambique. In J. Abbink, M. de Bruijn \& K. van Walraven (Eds.), Re-thinking resistance: Revolt and violence in African history (pp. 253-276). Boston: Brill.

Shaw, F. L. (1905). A tropical dependence: A, outline of the Ancient history of Western Soudan with an account of the modern settlement of Northern Nigeria. James Nisbet \& Co. Limited.

Siollun, M. (2009). Oil, politics, and violence: Nigeria's military coup culture (1966 - 1976). New York: Algora Publishing.

Smith, A. (1776). An inquiry into the nature and causes of the wealth of nations. (Metalibri Digital Edition 2007, New York: Metalibri

Sorokin, P. A. (1969). Society, culture, and personality: Their structure and dynamics: A system of general sociology. Cooper Square Publishers.

Stuchtey, B. (2011) Colonialism and imperialism, 1450-1950, in: European History Online (EGO), published by the Institute of European History (IEG), Mainz 2011-01-24. URL: http://www.ieg-ego.eu/stuchteyb-2010en URN: urn:nbn:de:0159-20101025319 [YYYY-MM-DD].

Thomas, H. (1997). The slave trade: The story of the Atlantic slave trade: 1440-1870. New York: Simon \& Schuster.

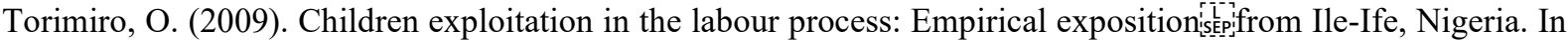
O. Agbu (Ed.), Children and youth in the labour process in Africa (pp. 35-62). Dakar - Senegal: Council for the Development of Social Science Research in Africa (CODESRIA).

UN. (2018). World youth report: Youth and the 2030 agenda for sustainable development. UN.

Von Soest, C. (2013). Persistent systemic corruption: Why democratisation and economic liberalisation have failed to undo an old evil: A six-country analysis. Zeitschrift für Vergleichende Politikwissenschaft, 7, 57-87. DOI 10.1007/s12286-013-0157-6.

Waller, R. (2006). Rebellious youth in colonial Africa. Journal of African History, 47(1), 82-83.

Wraith, R., \& E. Simpkins. (1963). Corruption in developing countries. London: George Allen \& Unwin Ltd.

Zoetti, P. A. (2020). It's wrong, but that's the way it is. Youth, violence and justice in North-Eastern Brazil. Social \& Legal Studies, https://doi.org/10.1177/0964663920915967 